УДК 389.14:621.317:006.354

T.B. Gordiyenko, $\mathrm{PhD}$, L.V. Kolomiets, ScD, O.M. Velychko, ScD

Odessa state academy of technical regulation and quality, Odessa.

\title{
ACTIVITY THE TECHNICAL COMMITTEES STANDARDIZATION OF INTERNATIONAL ORGANIZATIONS IN FIELD OF METROLOGY
}

The main scopes activities of technical committees of international organization in field of metrology are described. The main principles of harmonization of national standards with the international standards in field of metrology are defined. Possibility of interactions of technical committees of ISO, IEC and OIML are determined.

Keywords: technical committee, international standard, international document, international recommendation, national standard, harmonization.

Т.Б. Гордієнко, к.т.н., В.М. Коломієць, д.т.н., О.М. Величко, д.т.н.

\section{ДІЯЛЬНІСТЬ ТЕХНІЧНИХ КОМІТЕТІВ ЗІ СТАНДАРТИЗАЦІЇ МІЖНАРОДНИХ ОРГАНІЗАЦІЙ У СФЕРІ МЕТРОЛОГІї}

\begin{abstract}
Розглянуто основну діяльність технічних комітетів зі стандартизації міжнародних організацій в сфері мерології. Визначені основні приниипи гармонізації національних стандартів з міжснародними стандартами 8 сфері метрології. Встановлено можливості взаємодії між технічними комітетами ISO, IEC і OIML.
\end{abstract}

Ключові слова: технічні комітети, міжнародні стандарти, міжнародні документи, міжнародні рекомендації, начіональні стандарти, гармонізація.

Т.Б. Гордиенко, К.т.н., Л.В. Коломиец, д.т.н., О.Н. Величко, д.т.н.

\section{ДЕЯТЕЛЬНОСТЬ ТЕХНИЧЕСКИХ КОМИТЕТОВ ПО СТАНДАРТИЗАЦИИ МЕЖДУНАРОДНЫХ ОРГАНИЗАЦИЙ В СФЕРЕ МЕТРОЛОГИИ}

Рассмотрена основная деятельность технических комитетов по стандартизации международных организаций в сфере метрологии. Определень основные принципь гармонизации национальных стандартов $c$ международными стандартами в сфере метрологии. Выявлено возможности взаимодействия между техническими комитетами ISO, IEC и OIML.

Ключевые слова: технические комитеты, международные стандарты, международные документы, международные рекомендации, национальные стандарты, гармонизация.

\section{Introduction}

A mutual exchange with experience and information in field of metrology is very important. Many International Organizations is developing of voluntary technical standards in field of metrology (measurement, testing etc.), in particular it International Organization for Standardization (ISO), International Electrotechnical Commission (IEC) and International Organization of Legal Metrology (OIML) [1-4].

1. Main activity of International Organizations in field of metrology

ISO is a non-governmental organization and one of the world's foremost developers of voluntary technical standards. The ISO Central Secretariat manages an international standardization system, prepares, produces and disseminates international standards and standards-related documents. These services include coordination of the standards development programme, administration of voting on draft standards, the final editing and publication of standards, and information, communication and public relations [1].

Technical Management Board (TMB) is ISO body which developing standards or guides on all matters concerning the organization, coordination, strategic planning, and programming of the technical work of ISO including establishment and dissolution of technical committees (TC), particularly in field of metrology. 
ISO standards are developed by TC, subcommittees (SC) or project committees comprising experts from the industrial, technical and business sectors which have asked for the standards, and which subsequently put them to use. These experts may be joined by representatives of government agencies, testing laboratories, consumer associations, non-governmental organizations and academic circles. Each TC and SC has a secretariat assigned to an ISO member national body (for example, AFNOR, DIN, ANSI etc.).

Stakeholders in international standardization comprise all those groups who have an interest in international standardization because they are affected by it and wish therefore to contribute to the process of the development of international standards. Stakeholders participate in the technical work of ISO through national delegations appointed by the member national bodies of ISO or, if they are organized in international or broadly-based organizations, through liaison organizations.

In addition to international standards, ISO can also offer other forms of normative agreements (e. g. ISO Guide, ISO Publicly Available Specification (PAS), ISO Technical Specification (TS), ISO Technical Report (TR) for situations where speedy publication is important, has developed a schematic representation of the different types of deliverable available.

ISO engage introducing international standards for quantities and units which based in the International System of Units (SI) - ISO 80000 (14 parts). International standards of series ISO 9000 "Quality management systems", ISO 10012 "Measurement management systems" is important for National Metrological Institutes (NMIs). International standards ISO 3435 "Continuous mechanical handling equipment" and ISO 5725 "Accuracy (trueness and precision) of measurement methods and results" (six part) extensively used for handling measurements result. ISO Guide 30 "Terms and definitions used in connection with reference materials" and ISO Guide 35 "Reference materials. - General and statistical principles for certification" too use for metrological practice for reference materials.

ISO collaborates with its two sector based, international partners, the IEC, the United Nations Organization, other specialized organizations, agencies and commissions. Cooperative agreements are established between the ISO and IEC and certain institutions, such as OIML, International Laboratory Accreditation Cooperation (ILAC), etc., with the objective of avoiding contradictory requirements; consequently, manufacturers and users of measuring instruments, test laboratories, etc. may simultaneously apply ISO and IEC Publications and those of other institutions.
The IEC is the leading global organization that prepares and publishes international standards for all electrical, electronic and related technologies. These serve as a basis for national standardization and as references when drafting international tenders and contracts. The IEC charter embraces all electrotechnologies including electronics, magnetics and electromagnetics, electroacoustics, multimedia, telecommunication, and energy production and distribution, as well as associated general disciplines such as terminology and symbols, electromagnetic compatibility, measurement and performance, dependability, design and development, safety and the environment $[2,4]$.

The TCs and SCs, and many project teams/maintenance teams carry out the standards work of the IEC. These working groups (WG) are composed of people from all around the world who are experts in electrotechnology. The great majority of them come from industry, while others from commerce, government, test laboratories, research laboratories, academia, and consumer groups also contribute to the work.

OIML was established in order to promote the global harmonization of legal metrology procedures. OIML is an intergovernmental treaty organization whose membership includes member states, countries which participate actively in technical activities, and corresponding members, countries which join the OIML as observers. It was established in order to promote the global harmonization of legal metrology (LM) procedures.

The OIML has developed a worldwide technical structure that provides its members with metrological guidelines for the elaboration of national and regional requirements concerning the manufacture and use of measuring instruments for LM applications [3, 4].

International consensus in the LM community is reached through TCs and SCs, the composition of which includes representatives from OIML member states, international standardization and technical organizations, manufacturers' associations and regional regulatory bodies. Under the coordination of a secretariat, experts establish international technical guidelines for the metrological performance and testing procedures of measuring instruments (MI) subject to legal controls.

The OIML develops model regulations, International Recommendations (OIML R) and International Documents (OIML D), which provide members with an internationally agreed-upon basis for the establishment of national legislation on various categories of MI. It coordinates and informs International Committee of Legal Metrology (CIML) members of technical work undertaken by OIML TCs.

Cooperative agreements are established between the OIML and certain international 
organizations in field of standardization, with the objective of avoiding contradictory requirements; consequently, manufacturers and users of MI, test laboratories, etc. may simultaneously apply OIML Publications and those of other organizations. The main elements of an OIML R are: scope, application and terminology; metrological requirements; technical requirements; methods and equipment for testing and verifying conformity to requirements; and the test report format, etc.

International consensus in the LM community is reached through TCs and SCs, the composition of which includes representatives from OIML member states, international standardization and technical organizations, manufacturers' associations and regional regulatory bodies. Under the coordination of OIML Secretariat, experts establish international technical guidelines for the metrological performance and testing procedures of measuring instruments subject to legal controls. Draft OIML R and OIML D are developed by TCs or their SCs, which are formed by the OIML member states.

From 1993 Ukraine has become the ISO and IEC full member and participates in its TCs and SCs projects for preparation of international standards and other normative documents. ISO and IEC publications can be identified by their ISO or IEC number, through the International Classification for Standards (ICS) [5] system, or by the respective $\mathrm{TC} / \mathrm{SC}$ responsible for that publication.

From January 1997 Ukraine has become the OIML Corresponding Member. Such OIML Corresponding Member enables to get regularly the documents, recommendations and other printed matters of OIML and to use them for harmonization of the national normative bases on metrology with international documents and recommendations.

\section{Harmonization of National Standards with ISO and IEC Standards}

Structure of the ISO standards which developed ISO TCs and national standards of Ukraine (DSTU ISO) in the field of metrology are given in Table 1 by next codes of ICS [5]: 01.060 "Quantities and units"; 17 "Metrology and measurement. Physical phenomena" and 71.040 "Analytical chemistry". Total ISO standards in the field of metrology are 563 [6-8].

Structure of the IEC standards which developed IEC TCs and national standards of Ukraine (DSTU IEC) in the field of metrology is given in Table 2 by next codes of ICS [5]: 01.060 "Quantities and units"; 17 "Metrology and measurement. Physical phenomena"; 25.040.040 "Industrial process measurement and control"; 71.040 "Analytical chemistry". Total IEC standards in the field of metrology are 180.
Table 1 - Structure of ISO standards which developed ISO TCs and national standards in fields of metrology

\begin{tabular}{|c|c|c|}
\hline \multirow{2}{*}{ Name of ISO TC } & \multicolumn{2}{|c|}{$\begin{array}{c}\text { Total } \\
\text { of standards }\end{array}$} \\
\hline & ISO & $\begin{array}{l}\text { DSTU } \\
\text { ISO }\end{array}$ \\
\hline $\begin{array}{l}\text { TC } 12 \text { Quantities, units, } \\
\text { symbols, conversion factors }\end{array}$ & 16 & $\begin{array}{c}1 \\
(\mathrm{MOD}) \\
*\end{array}$ \\
\hline $\begin{array}{l}\text { TC } 30 \text { Measurement of fluid } \\
\text { flow in closed conduits }\end{array}$ & 40 & 4 \\
\hline TC 48 Laboratory equipment & 90 & 3 \\
\hline $\begin{array}{l}\text { TC } 69 \text { Applications of } \\
\text { statistical methods }\end{array}$ & 24 & 5 \\
\hline TC 85 Nuclear energy & 59 & 6 \\
\hline $\begin{array}{l}\text { TC } 108 \text { Mechanical vibration, } \\
\text { shock and condition monitoring }\end{array}$ & 114 & 14 \\
\hline TC 113 Hydrometry & 69 & 3 \\
\hline TC 158 Analysis of gases & 23 & 7 \\
\hline TC 172 Optics and photonics & 21 & 4 \\
\hline $\begin{array}{l}\text { TC } 213 \text { Dimensional and } \\
\text { geometrical product } \\
\text { specifications and verification }\end{array}$ & 107 & 15 \\
\hline Total: & 563 & 62 \\
\hline
\end{tabular}

Table 2 - Structure of IEC standards which developed IEC TCs and national standards in fields of metrology

\begin{tabular}{|c|c|c|}
\hline \multirow{2}{*}{ Name of IEC TC } & \multicolumn{2}{|c|}{$\begin{array}{c}\text { Total } \\
\text { of standards }\end{array}$} \\
\hline & IEC & $\begin{array}{l}\text { DSTU } \\
\text { IEC }\end{array}$ \\
\hline TC 1 Terminology (for MI) & 10 & 2 \\
\hline $\begin{array}{l}\text { TC } 13 \text { Electrical energy } \\
\text { measurement, tariff- and load } \\
\text { control }\end{array}$ & 16 & 5 \\
\hline TC 25 Quantities and units & 21 & - \\
\hline TC 29 Electroacoustics & 50 & - \\
\hline TC 38 Instrument transformers & 8 & - \\
\hline TC 45 Nuclear instrumentation & 15 & 1 \\
\hline $\begin{array}{l}\text { TC } 65 \text { Industrial-process } \\
\text { measurement, control and } \\
\text { automation }\end{array}$ & 10 & 1 \\
\hline $\begin{array}{l}\text { TC } 66 \text { Safety of measuring, } \\
\text { control and laboratory } \\
\text { equipment }\end{array}$ & 10 & 3 \\
\hline $\begin{array}{l}\text { TC } 85 \text { Measuring equipment } \\
\text { for electrical and } \\
\text { electromagnetic quantities }\end{array}$ & 40 & $\begin{array}{c}13 \\
3 \\
(\mathrm{MOD}) \\
*\end{array}$ \\
\hline Total: & 180 & 28 \\
\hline
\end{tabular}

* The DSTU IEC standards is modified concerning to IEC standards 


\section{Joint ISO/IEC Standards and Guides for metrological tasks}

The ISO, IEC and OIML participate in the Joint Committee for Guides in Metrology (JCGM), and the Joint Committee on Coordination of Assistance to Developing Countries in Metrology, Accreditation and Standardization (JCDCMAS).

The JCGM has responsibility for the following two important for metrology documents: Guide to the Expression of Uncertainty in Measurement (GUM) [9]; and International Vocabulary of Metrology - Basic and General Concepts and Associated Terms (VIM) [10]. The JCGM-WG1 has recently completed its first Supplement to the GUM. The JCGM-WG2 has recently completed a revised edition of the VIM (VIM).

Developing and publishing joint international standards and guides are important element of activity of international organizations for standardization. International standards ISO/IEC 17025 "General requirements for the competence of testing and calibration laboratories" and international guides ISO/IEC 17043 "Conformity assessment. - General requirements for proficiency testing", ISO/IEC Guide 2 "Standardization and related activities. - General vocabulary" are establishing requirements for quality systems, especially NMI, and requirements for accreditation independent laboratory, especially calibration laboratories.

As shown in Table 3 the system of international standards, documents and recommendations, national standards in field of metrology includes the main blocks of standards [11, 12].

Table 3 - Harmonization of national standards in fields of metrology with general international standards, documents, recommendations

\begin{tabular}{|c|c|c|}
\hline $\begin{array}{c}\text { Object of } \\
\text { standardization }\end{array}$ & ISO, IEC & DSTU \\
\hline $\begin{array}{l}\text { Units of } \\
\text { measurement }\end{array}$ & ISO 80000 & $\begin{array}{c}\text { DSTU } 3651.1 \\
\text { DSTU } 3651.0 \\
- \\
\end{array}$ \\
\hline $\begin{array}{l}\text { Measurement } \\
\text { management } \\
\text { systems } \\
\end{array}$ & ISO 10012 & DSTU ISO 10012 \\
\hline $\begin{array}{l}\text { Accreditation of } \\
\text { calibration labs }\end{array}$ & $\begin{array}{c}\text { ISO/IEC } \\
17025\end{array}$ & $\begin{array}{c}\text { DSTU ISO/IEC } \\
17025\end{array}$ \\
\hline $\begin{array}{l}\text { Quality management } \\
\text { systems }\end{array}$ & $\begin{array}{l}\text { ISO } 9000 \\
\text { ISO } 9001\end{array}$ & $\begin{array}{l}\text { DSTU ISO } 9000 \\
\text { DSTU ISO } 9001\end{array}$ \\
\hline $\begin{array}{l}\text { Accuracy of } \\
\text { measurement } \\
\text { methods and results }\end{array}$ & $\begin{array}{c}\text { ISO } 5725- \\
1 \ldots 6\end{array}$ & $\begin{array}{c}\text { DSTU GOST } \\
\text { ISO } 5725-1 \ldots 6\end{array}$ \\
\hline $\begin{array}{l}\text { Certified reference } \\
\text { materials }\end{array}$ & $\begin{array}{l}\text { ISO Guide } 30 \\
\text { ISO Guide } 35\end{array}$ & $\begin{array}{c}-- \\
\text { DSTU-H ISO } \\
\text { Guide } 35 \\
\end{array}$ \\
\hline $\begin{array}{l}\text { Proficiency testing } \\
\text { by interlaboratory } \\
\text { comparisons }\end{array}$ & $\begin{array}{c}\text { ISO/IEC } \\
17043\end{array}$ & - \\
\hline
\end{tabular}

\section{Harmonization of National Standards with OIML Documents and Recommendations}

International consensus in the LM community is reached through TCs and SCs, the composition of which includes representatives from OIML member states, international standardization and technical organizations, manufacturers' associations and regional regulatory bodies. Under the coordination of OIML Secretariat, experts establish international technical guidelines for the metrological performance and testing procedures of MI subject to legal controls.

General structure of the OIML Publications in the field of metrology and corresponding harmonization of the national standards of Ukraine (DSTU OIML) is given in Table 4 [12].

Table 4 - Structure of OIML Publications which developed OIML TCs and National Standards in fields of metrology

\begin{tabular}{|l|c|c|}
\hline \multirow{2}{*}{ Name of OIML TCs } & \multicolumn{2}{|c|}{$\begin{array}{c}\text { Total } \\
\text { publications }\end{array}$} \\
\cline { 2 - 3 } & $\begin{array}{c}\text { OIML } \\
\text { (D/R/V) }\end{array}$ & $\begin{array}{c}\text { DSTU } \\
\text { OIML }\end{array}$ \\
\hline TC 1 Terminology & $0 / 0 / 1$ & - \\
\hline TC 2 Units of measurement & $1 / 0 / 0$ & 1 \\
\hline TC 3 Metrological control & $11 / 2 / 0$ & 9 \\
\hline $\begin{array}{l}\text { TC 4 Measurement standards } \\
\text { and calibration and verification } \\
\text { devices }\end{array}$ & $4 / 0 / 0$ & 3 \\
\hline $\begin{array}{l}\text { TC 5 General requirements for } \\
\text { measuring instruments }\end{array}$ & $2 / 0 / 0$ & 1 \\
\hline TC 6 Prepackaged products & $0 / 3 / 0$ & 2 \\
\hline $\begin{array}{l}\text { TC 7 Measuring instruments for } \\
\text { length and associated quantities }\end{array}$ & $0 / 10 / 0$ & 1 \\
\hline $\begin{array}{l}\text { TC 8 Measurement of quantities } \\
\text { of fluids }\end{array}$ & $4 / 26 / 0$ & 9 \\
\hline $\begin{array}{l}\text { TC 9 Instruments for measuring } \\
\text { mass and density }\end{array}$ & $1 / 21 / 0$ & 5 \\
\hline $\begin{array}{l}\text { TC 10 Instruments for measuring } \\
\text { pressure, force and associated } \\
\text { quantities }\end{array}$ & $0 / 7 / 0$ & 1 \\
\hline $\begin{array}{l}\text { TC 11 Instruments for measuring } \\
\text { temperature and associated } \\
\text { quantities }\end{array}$ & $1 / 8 / 0$ & - \\
\hline $\begin{array}{l}\text { TC 12 Instruments for measuring } \\
\text { electrical quantities }\end{array}$ & $0 / 0 / 0$ & - \\
\hline $\begin{array}{l}\text { TC 13 Measuring instruments } \\
\text { for acoustics and vibration }\end{array}$ & $0 / 10 / 0$ & - \\
\hline $\begin{array}{l}\text { TC 14 Measuring instruments } \\
\text { for used for optics }\end{array}$ & $0 / 1 / 0$ & - \\
\hline $\begin{array}{l}\text { TC 15 Measuring instruments } \\
\text { for ionizing radiations }\end{array}$ & $1 / 3 / 0$ & - \\
\hline $\begin{array}{l}\text { TC 16 Instruments for } \\
\text { measuring pollutants }\end{array}$ & $1 / 10 / 0$ & - \\
\hline $\begin{array}{l}\text { TC 17 Instruments for physical- } \\
\text { chemical measurements }\end{array}$ & $1 / 10 / 0$ & - \\
\hline $\begin{array}{l}\text { TC 18 Medical measuring } \\
\text { instruments }\end{array}$ & $0 / 11 / 0$ & - \\
\hline & $27 / 122 / 1$ & 32 \\
\hline
\end{tabular}


As shown in Table 5 the system of international standards, documents and recommendations, national standards in field of metrology includes the following main blocks of standards:

- terminology;

- $\quad$ traceability;

- $\quad$ units of measurements;

- $\quad$ measurement standards of units;

- $\quad$ state and local verification schemes;

- $\quad$ general requirements for MI;

- $\quad$ MI metrological characteristics;

- $\quad$ MI tests;

- $\quad$ MI verification and calibration;

- $\quad$ metrological inspection and supervision;

- metrological supervision for prepackaged goods;

- accreditation of measurement and calibration laboratories.

Thus, in Ukraine there are 32 national standards witch harmonized to some extent with OIML dictionaries, documents or recommendations. The main way for harmonization of national standards is a direct introducing of the OIML documents or recommendations (translation on Ukrainian with some national revision or additions, if needed). It is planned to harmonize 5 national standards with OIML recommendations in the near future.

The general analysis of normative base on questions of metrology shows that in Ukraine, in spite of the availability of sufficient complex of basic national standards, still it is required both the development of new standards and revision of some valid standards (Fig. 1).
Table 5 - System of general international standards, documents, recommendations and national standards in fields of metrology

\begin{tabular}{|c|c|c|}
\hline \begin{tabular}{|c|} 
Object of \\
standardization
\end{tabular} & $\begin{array}{c}\text { OIML } \\
(\mathrm{D}, \mathrm{R}, \mathrm{V})\end{array}$ & DSTU OIML \\
\hline Terminology & $\begin{array}{l}\text { OIML V1 } \\
\text { OIML V2 }\end{array}$ & $\begin{array}{l}- \\
-\end{array}$ \\
\hline Traceability & \begin{tabular}{|l} 
OIML D1 \\
OIML D13
\end{tabular} & $\begin{array}{c}- \\
\text { DSTU OIML D13 }\end{array}$ \\
\hline $\begin{array}{l}\text { Units of } \\
\text { measurement }\end{array}$ & OIML D2 & DSTU OIML D2* \\
\hline $\begin{array}{l}\text { Measurement } \\
\text { standards }\end{array}$ & OIML D8 & DSTU OIML D8 \\
\hline $\begin{array}{l}\text { Verification } \\
\text { hierarchy } \\
\text { schemes }\end{array}$ & OIML D5 & DSTU OIML D5* \\
\hline $\begin{array}{l}\text { General } \\
\text { requirements } \\
\text { for MI }\end{array}$ & $\begin{array}{l}\text { OIML D3 } \\
\text { OIML D11 } \\
\text { OIML R34 } \\
\text { OIML R99-1 } \\
\text { OIML R99-2 } \\
\text { OIML R99-3 }\end{array}$ & \begin{tabular}{|} 
DSTU OIML D3 \\
DSTU OIML D11 \\
DSTU OIML R34* \\
- \\
- \\
-
\end{tabular} \\
\hline $\begin{array}{l}\text { Metrological } \\
\text { control }\end{array}$ & \begin{tabular}{|l|} 
OIML D16 \\
OIML D19
\end{tabular} & \begin{tabular}{|l|} 
DSTU OIML D16 \\
DSTU OIML D19
\end{tabular} \\
\hline $\begin{array}{l}\text { Verification } \\
\text { and calibration } \\
\text { for MI }\end{array}$ & \begin{tabular}{|l} 
OIML D12 \\
OIML D20 \\
OIML D23 \\
OIML R42
\end{tabular} & $\begin{array}{c}\text { DSTU OIML D12* } \\
\text { DSTU OIML D20 } \\
\text { DSTU OIML D23 } \\
-\end{array}$ \\
\hline $\begin{array}{l}\text { Certified } \\
\text { reference } \\
\text { materials }\end{array}$ & OIML D18 & DSTU OIML D18 \\
\hline $\begin{array}{l}\text { Metrological } \\
\text { supervision }\end{array}$ & OIML D9 & DSTU OIML D9 \\
\hline $\begin{array}{l}\text { Prepackaged } \\
\text { products }\end{array}$ & \begin{tabular}{|l|} 
OIML R79 \\
OIML R87
\end{tabular} & \begin{tabular}{|l|} 
DSTU OIML R79 \\
DSTU OIML R87
\end{tabular} \\
\hline $\begin{array}{l}\text { Accreditation } \\
\text { of calibration } \\
\text { labs }\end{array}$ & $\begin{array}{l}\text { ILAC-G24/ } \\
\text { OIML D10 }\end{array}$ & $\begin{array}{l}\text { DSTU ILAC-G24/ } \\
\text { OIML D10* }\end{array}$ \\
\hline
\end{tabular}

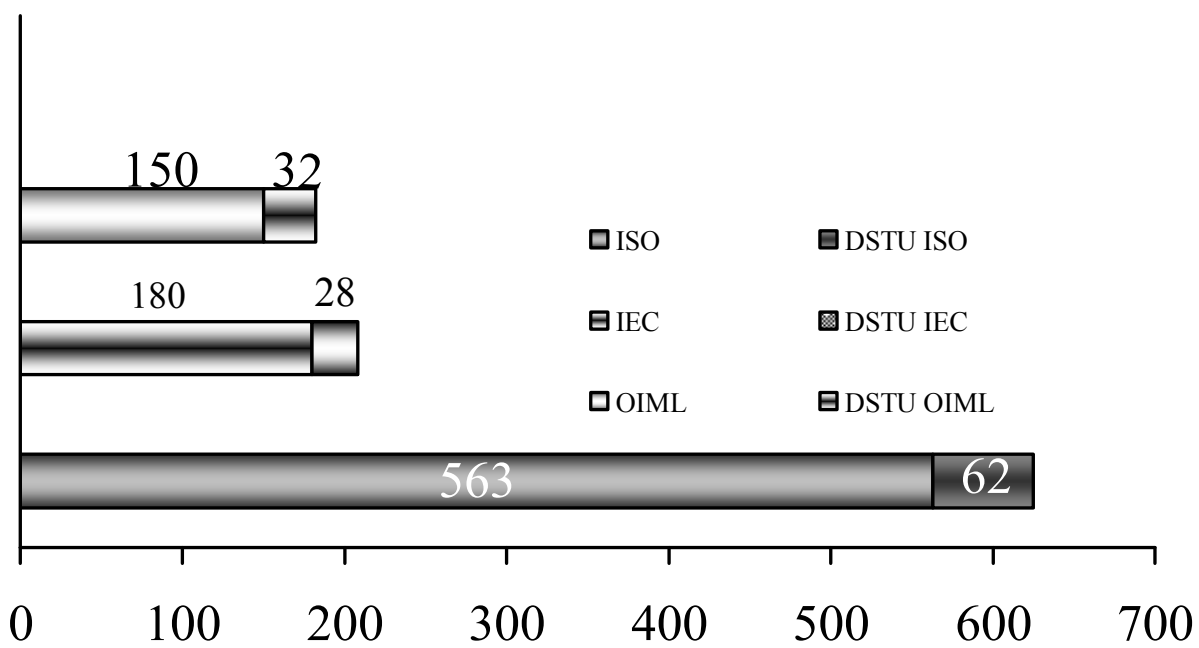

Figure 1 - Total international standards which developed

ISO, IEC and OIML TCs in field of metrology and harmonized with them DSTU 
Taking into consideration the international practice on metrology would allow to draw nearer the metrological system of Ukraine to requirements generally accepted in the world and hereunder it would ensure both the acceptance of the results of measurements, which are carried out in Ukraine, and the results of the industrial product testing all over the world. This would contribute to a rising of competitiveness of Ukrainian enterprises on markets of the world.

\section{Conclusions}

ISO and IEC membership enables to get regularly the international standards and guides, and other printed matters of ISO and IEC, and to use them for harmonization of the national standards in field of metrology with international standards and guides.

OIML membership enables to get regularly the documents, recommendations and other printed matters of OIML and to use them for harmonization of the national standards in field of metrology with international documents and recommendations.

Analyses activity of OIML and international metrological organization or consultative committees and international organization for standardization technical committees in field of metrology (measurement and instrumentation) has shown commonness interest and aims on different levels of works.

OIML, ISO and IEC membership enables to get regularly the documents, recommendations and other printed matters of OIML, ISO and IEC and to use them for harmonization of the national standards in field of metrology with international documents, recommendations, standards and guides.

\section{References}

1. International Organization for Standardization ISO. - Режим доступу: http://www.iso.org.

2. International Electrotechnical Commission - IEC. - Режим доступу: http://www.iec.org.

3. International Organization of Legal Metrology OIML. - Режим доступу: http://www.oiml.org.

4. O. Velychko. Activity of international and regional organization for globalization of the world economy. XVIII IMEKO World Congress. - Rio de Janeiro, Brazil. - 2006. - CD. -6 p.

5. International Classification for Standards (ICS). Fifth edition. - ISO. - 2001

6. O. N. Velichko. Metrological activity in Ukraine // Measurement Techniques. - Vol. 42. - Numb. 12. - December, 1999. - P. 1109 - 1115.

7. O. Velychko. Harmonization of the legislative acts and normative documents on metrology in Ukraine // OIML Bulletin. - Vol. XLI. - Numb. 2. April 2000. - P. 19-24.

8. O. Velychko Implementation of the European Directive on Measurement Instruments in Ukraine // OIML Bulletin. - Vol. LI. - Number 3. - July 2010. - P. 11-16.

9. ISO/IEC Guide 98-3:2008. Uncertainty of measurement. - Part 3: Guide to the expression of uncertainty in measurement (GUM: 1995). - First edition. - ISO. - 2008. - $120 \mathrm{p}$.

10. ISO/IEC Guide 99:2007. International vocabulary of metrology. - Basic and general concepts and associated terms (VIM). - First edition. - ISO. - 2007. $-90 \mathrm{p}$.

11. O. Velychko. Metrological activity in Ukraine // OIML Bulletin. - Vol. XXXVIII. - Number 3. July 1997. - P. 36-41.

12. O. Velychko, T. Gordiyenko. Implementation of the European Directive on Measurement Instruments in Ukraine // OIML Bulletin. - Vol. LI. - Number 2. - April 2010. - P. 23-29.

Рецензент: д.т.н., с.н.с. Братченко Г.Д., Одеська державна академія технічного регулювання та якості, Одеса 